\title{
Binding of Tissue Plasminogen Activator to Cultured Human Endothelial Cells
}

\author{
Katherine A. Hajjar, ${ }^{\star \ddagger}$ Nancy M. Hamel, Peter C. Harpel, ${ }^{\ddagger}$ and Ralph L. Nachman ${ }^{\ddagger}$ \\ Divisions of Hematology-Oncology, Departments of ${ }^{*}$ Pediatrics and ${ }^{\ddagger}$ Medicine, and the Specialized Center of Research in Thrombosis, \\ Cornell University Medical College, New York 10021
}

\begin{abstract}
Tissue plasminogen activator (t-PA) and urokinase (u-PA), the major activators of plasminogen, are synthesized and released from endothelial cells. We previously demonstrated specific and functional binding of plasminogen to cultured human umbilical vein endothelial cells (HUVEC). In the present study we found that t-PA could bind to HUVEC. Binding of t-PA to HUVEC was specific, saturable, plasminogen-independent, and did not require lysine binding sites. The t-PA bound in a rapid and reversible manner, involving binding sites of both high $\left(K_{d}, 28.7 \pm 10.8 \mathrm{pM} ; B_{\max }, 3,700 \pm 300\right)$ and low $\left(K_{d}\right.$, $\left.18.1 \pm 3.8 \mathrm{nM} ; B_{\max } 815,000 \pm 146,000\right)$ affinity. t-PA binding was $70 \%$ inhibited by a 100 -fold molar excess of u-PA. When t-PA was bound to HUVEC, its apparent catalytic efficiency increased by three- or fourfold as measured by plasminogen activation. HUVEC-bound t-PA was active site-protected from its rapidly acting inhibitor: plasminogen activator inhibitor. These results demonstrate that t-PA specifically binds to HUVEC and that such binding preserves catalytic efficiency with respect to plasminogen activation. Therefore, endothelial cells can modulate hemostatic and thrombotic events at the cell surface by providing specific binding sites for activation of plasminogen.
\end{abstract}

\section{Introduction}

Human tissue plasminogen activator (t-PA) ${ }^{1}$ is a single chain serine protease of $M_{\mathrm{r}} 68,000$. This enzyme is synthesized and secreted by endothelial cells and is one of the two major circulating plasminogen activators (1). After cleavage with plasmin $(2,3)$, two distinct portions of the molecule have been defined,

Address correspondence to Katherine A. Hajjar, M.D., Division of Hematology-Oncology, Department of Medicine, Cornell University Medical College, 1300 York Ave., New York, NY 10021.

Received for publication 22 December 1986 and in revised form 29 April 1987.

1. Abbreviations used in this paper: AFC, 7-amino-4-trifluoromethylcoumarin; $\alpha_{2} \mathrm{PI}, \alpha_{2}$ antiplasmin; $\mathrm{B}_{\max }$, number of binding sites per cell; EACA, $\epsilon$-aminocaproic acid; HUVEC, human umbilical vein endothelial cells; $\mathrm{IB}(0), 11 \mathrm{mM} n$-2-hydroxyethylpiperazine- $n$ '-2-ethanesulfonic acid, $137 \mathrm{mM} \mathrm{NaCl}, 4 \mathrm{mM} \mathrm{KCl}, 3 \mathrm{mM} \mathrm{CaCl}, 1 \mathrm{mM} \mathrm{MgCl} 2,11$ $\mathrm{mM}$ glucose; IB(2), IB(0) containing $2 \mathrm{mg} / \mathrm{ml} \mathrm{BSA}$;B(5), IB(0) containing $5 \mathrm{mg} / \mathrm{ml} \mathrm{BSA} ; \mathrm{K} 123$, elastase-derived "kringle" 1,2,3 fragment of plasminogen; $k_{\text {cat }}$, catalytic rate constant; LDH, lactate dehydrogenase; PAI; plasminogen activator inhibitor; PCM, postculture medium; tAMCHA, tranexamic acid; t-PA, tissue plasminogen activator; u-PA, urokinase.

J. Clin. Invest.

(c) The American Society for Clinical Investigation, Inc.

0021-9738/87/12/1712/08 $\$ 2.00$

Volume 80, December 1987, 1712-1719 an 'A' or heavy chain $\left(M_{\mathrm{r}} 36,000\right)$ possessing two plasminogen-like "kringle" structures, an epidermal growth factor-like region, and a fibronectin-like "finger" structure, plus a 'B' or light chain $\left(M_{\mathrm{r}} 32,000\right)$ which contains the active site $(4,5)$. The light chain of t-PA shows considerable homology with other serine proteases $(6,7)$. For optimal activity, t-PA requires fibrin as a cofactor that augments its catalytic efficiency by two to three orders of magnitude, possibly via formation of a cyclic ternary complex involving t-PA, plasminogen, and fibrin (8). Other proteins such as thrombospondin and histidine-rich glycoprotein may also enhance the enzymatic activity of t-PA in vitro (9).

In addition to t-PA, cultured endothelial cells synthesize and secrete urokinase-like plasminogen activators (u-PA) $(10-12)$, and a plasminogen activator inhibitor (PAI) $(10,13)$. In the resting state, both forms of plasminogen activator are measurable in plasma $(50-100 \mathrm{pM}$ and $\sim 100 \mathrm{pM}$, respectively), and additional t-PA is released from the vascular wall after various stimuli (14). Cultured bovine capillary endothelial cells secrete t-PA into the medium, and binding to the surface is minimal (15). However, it is not clear whether large vessel endothelial cells behave similarly. In contrast, u-PA binds to human monocytes and a monocytic cell line (U937) $(16,17)$, normal and virus-transformed fibroblasts $(3 \mathrm{~T} 3)(18$, 19), a human epidermoid carcinoma (A431) cell line (20-22), and possibly bovine corneal (23) and capillary (15) endothelial cells.

We recently reported binding and activation of human glu-plasminogen on the surface of cultured human umbilical vein endothelial cells (HUVEC) (24). Binding was specific, of high affinity, and associated with a log-order increase in catalytic activity when bound zymogen was activated by t-PA. We now demonstrate plasminogen-independent, specific, and saturable binding of t-PA to both high- and low-affinity sites on the HUVEC surface. Binding was independent of the lysinebinding sites of t-PA, and was $70 \%$ inhibitable by a 100 -fold molar excess of urokinase. t-PA binding to HUVEC was associated with preservation of enzyme activity as determined by plasminogen activation, and binding protected t-PA from its fast-acting inhibitor, PAI.

\section{Methods}

Materials. 96 (Falcon Labware, Oxnard, CA) and 24 (Costar, Cambridge, MA)-well tissue culture plates were employed. L-Glutamine, penicillin-streptomycin, fungizone, porcine intestinal mucosal heparin, BSA (essentially fatty acid- and globulin-free), lactoperoxidase, tissue culture grade EDTA, $p$-nitrophenylphosphate, $l$-arginine, and l-lysine were from Sigma Chemical Co., St. Louis, MO. Collagenase (type I) was obtained from Worthington Diagnostics, Bedford, MA, lysine-Sepharose and Concanavalin A-Sepharose from Pharmacia Fine Chemicals, Piscataway, NJ, diethanolamine from Fisher Scientific, Springfield, NJ, $\epsilon$-aminocaproic acid from Aldrich Chemical Co., Milwaukee, WI, and tranexamic acid from Kabi, Stockholm, Sweden. Serum-free medium (PC-1) was purchased from Ventrex Laboratories 
Inc., Portland, ME. Pooled human serum was obtained from the New York Blood Center.

Purified proteins. Human recombinant tissue plasminogen activator (t-PA) was provided by Genentech Inc., South San Francisco, CA. Samples were assessed by SDS-PAGE, and only "single-chain" $t-P A$ was used. Activity of t-PA was assessed in a fluid phase fluorogenic plasminogen activation assay with urokinase as standard. Urokinase (winkinase) was obtained from Sterling-Winthrop Research Institute, Rensselaer, NY. Human glu-plasminogen and fibrinogen were purchased from IMCO, Stockholm, Sweden. Murine epidermal growth factor (receptor grade) and human prothrombin were from Calbiochem-Behring Corp., La Jolla, CA; human fibronectin was kindly provided by Dr. Domenick Falcone, Cornell University Medical College. The elastase-derived "kringle 1,2,3" fragment (K123) of human plasminogen was prepared by the method of Sottrup-Jenson et al. (25). Recombinant human interleukin-1 (IL-1) was provided by Dr. Charles Dinarello, Tufts University School of Medicine, Boston, MA. Rabbit anti-human t-PA was kindly supplied by Dr. Nils Bang, Eli Lilly, Indianapolis, IN, rabbit anti-human plasminogen activator-1 by Dr. E. K. O. Kruithof, Centre Hospitalier Universitaire Vaudois, Lausanne, Switzerland, mouse anti- $F_{c}$ receptor by Damon Biotech, Needham Heights, MA. Rabbit anti-human prothrombin was purchased from Calbiochem-Behring Corp., and alkaline phosphatase-conjugated goat anti-rabbit was from CooperBiomedical, Inc., Malvern, PA.

Cell culture. Early passage (P2-5) human umbilical vein endothelial cells (HUVEC) were cultured in plasminogen-depleted human serum $(<1 \%)(24)$. For binding or activation studies the cells were used at confluency $(20,000-30,000$ cells/well). These cells did not react in ELISAs with antibodies to human albumin, $\alpha_{1}$-antitrypsin, $\alpha_{2}$-plasmin inhibitor, $\alpha_{2}$-macroglobulin, or histidine-rich glycoprotein. The cell surface was specifically unreactive toward fibrinogen at an antibody dilution of 1:500. At this level, the antibody could detect human fibrinogen applied to polystyrene wells in coating concentrations as low as $0.147 \mathrm{fmol} /$ well. Cell monolayers reacted strongly with rabbit antiserum to human lung angiotensin converting enzyme, rabbit antiserum to whole HUVEC, and with rabbit IgG directed against human fibronectin, each at dilutions of up to 1:50,000.

Cell quantitation. Each well to be counted was washed once with Hepes-buffered saline. Cells were detached by incubation $(20 \mathrm{~min}$, $37^{\circ} \mathrm{C}$ ) with Hepes-buffered saline containing $0.05 \%$ type I collagenase, $0.01 \%$ EDTA, and $0.25 \%$ BSA. After gentle trituration, the single-cell suspensions were enumerated in a hemocytometer. Counts were verified in an electronic apparatus (Model ZBI, Coulter Electronics Inc., Hialeah, FL). Trypan blue exclusion by the cells was $98 \%$.

Cell monolayer ELISAs. Cell monolayer ELISAs were carried out essentially as previously described (24). For t-PA binding studies, monolayers were equilibrated to $4^{\circ} \mathrm{C}(5 \mathrm{~min})$, washed once with incubation buffer (IB[2]), once with IB(2) containing $10 \mathrm{mM}$ EACA, and three times again with $\mathrm{IB}(2)$. Various concentrations of $t-\mathrm{PA}$ or other control proteins $(100 \mu \mathrm{l} /$ well $)$ were then added and the plates incubated at $4^{\circ} \mathrm{C}$ for various time periods. The monolayers were then washed three times with cold $\mathrm{IB}(2)$, lightly fixed with $0.02 \%$ glutaraldehyde, washed again three times, and exposed to rabbit anti-human t-PA $(3 \mathrm{~h}$, $37^{\circ} \mathrm{C}$ ). After three additional washes, the cells were exposed to alkaline phosphatase-conjugated goat anti-rabbit $\operatorname{IgG}\left(3 \mathrm{~h}, 37^{\circ} \mathrm{C}\right.$ or $\left.18 \mathrm{~h}, 4^{\circ} \mathrm{C}\right)$. After three final washes, the alkaline phosphatase substrate $p$-nitrophenylphosphate was added and substrate hydrolysis monitored at 405 $\mathrm{nm}$ as a reflection of protein binding.

Radioisotope labeling. Human recombinant t-PA was radio-iodinated by the lactoperoxidase method (26). Labeling was carried out for 3 min at $20^{\circ} \mathrm{C}$ in a total volume of $390 \mu \mathrm{l}$ at $\mathrm{pH} 7.4$ using a reaction mixture consisting of $4.4 \mu \mathrm{M}$ t-PA, $13 \mu \mathrm{mM}$ benzamidine, $1.3 \mu \mathrm{M}$ EDTA, $22 \mathrm{U} / \mathrm{ml}$ lactoperoxidase, $70 \mu \mathrm{M} \mathrm{H}_{2} \mathrm{O}_{2}$ in PBS containing $0.01 \%$ Tween 80 . The reaction was stopped with excess $\mathrm{KI}$ and bound ${ }^{125}$ I separated from unbound on a Sephadex G-25 column. t-PA activity in radio-iodinated samples was comparable to starting material as assessed by a fluid phase fluorometric assay of plasminogen activation. Structural integrity of all radiolabeled samples was monitored by
SDS-polyacrylamide gel autoradiography. Labeled t-PA was stored at $-70^{\circ} \mathrm{C}$ in the presence of $0.1 \%$ gelatin.

SDS-PAGE. Samples were dissolved in $5 \%$ SDS, $50 \mathrm{mM}$ Tris, 5 $\mathrm{mM}$ EDTA, $25 \%$ sucrose (wt/vol), and $50 \mu \mathrm{g} / \mathrm{ml}$ bromphenol blue. Reduced samples were heated to $100^{\circ} \mathrm{C}$ for $10 \mathrm{~min}$ in the presence of $200 \mathrm{mM}$ dithiothreitol. Samples were applied to 9\% Laemmli (27) slab gels (3.9\% stacking gels), and electrophoresed overnight at constant power. The gels were fixed in $10 \%$ methanol $/ 7 \%$ acetic acid, dried, and autoradiographed.

${ }^{125} I-t-P A$ binding studies. Measurement of ${ }^{125} \mathrm{I}-\mathrm{t}-\mathrm{PA}$ binding to HUVEC was carried out as described previously for ${ }^{125} \mathrm{I}$-plasminogen (24). Cells were grown to confluency in gelatin or fibronectin-coated 24-well tissue culture plates, washed once with IB(5), once with IB(5)/ $10 \mathrm{mM}$ EACA, and three times with IB(5). Cell counts were then performed. Various concentrations of trace-labeled ${ }^{125} \mathrm{I}$-t-PA were added to duplicate wells $(450 \mu \mathrm{l} /$ well $)$, and the plates incubated at $4^{\circ} \mathrm{C}$ for $30 \mathrm{~min}$. Aliquots $(100 \mu \mathrm{l})$ of free ${ }^{125} \mathrm{I}$-t-PA were counted in a 1185 gamma counter (Searle Radiographics, Des Plaines, IL). HUVEC were then washed rapidly, solubilized in $1 \%$ SDS, $0.5 \mathrm{M} \mathrm{NaOH}, 0.01 \mathrm{M}$ EDTA, and 100- $\mu$ l aliquots counted as described above. The data were analyzed using the "Ligand" program for fitting multiple binding sites (Biomedical Computing Technology Information Center, Vanderbilt University, Nashville, TN) (28). The Ligand program was used to estimate $K_{\mathrm{d}}$ and $\mathrm{B}_{\max }$ using both one- and two-site models.

Fluorometric assay for $t$-PA activation of plasminogen. Plasminogen activation by both fluid phase and HUVEC-bound t-PA was carried out as previously described (24). Confluent HUVEC were washed five times and incubated with various concentrations of t-PA at $4^{\circ} \mathrm{C}$. The monolayers were then rapidly washed three times (wash time, $<35 \mathrm{~s}$ ), and immediately thereafter a plasmin substrate (D-val-leu-lys7-amino-4-trifluoromethyl-coumarin; $165 \mu \mathrm{M}$ final concentration), human glu-plasminogen (75-328 $\mathrm{nM}$ final), and IB(2) were added to give a total volume of $300 \mu \mathrm{l}$. In some experiments, t-PA activity was measured in the presence of Con A eluates of post-culture medium from interleukin 1-stimulated EC; under these circumstances, t-PA activity was measured in the presence of $31 \mathrm{mM} \alpha$-methylmannoside.

Plasminogen activator inhibitor (PAI). Confluent HUVEC in T25 tissue culture flasks were washed twice with serum-free medium (PC-1), and then treated with recombinant human interleukin 1 (IL-1) at $0,10.6$, or $53.2 \mathrm{ng} / \mathrm{ml}$ in PC-1 for $18 \mathrm{~h}(29)$. Postculture medium $(\mathrm{PCM})$ was harvested and passed twice over a Con A column $(0.3 \mathrm{ml})$ $(13,30)$ previously equilibrated with PBS, $0.01 \%$ Tween $80,0.02 \%$ $\mathrm{NaN}_{3}$ (PBS-Tw80- $\mathrm{N}_{3}$ ). After washes with 10 column volumes of PBSTw80- $\mathrm{N}_{3}$ containing $1 \mathrm{M} \mathrm{NaCl}$ and 10 column volumes of PBSTw80- $\mathrm{N}_{3}$ alone, the column was eluted with $0.5 \mathrm{M} \alpha$-methylmannoside in the same buffer. Fractions $(100 \mu \mathrm{l})$ were collected and urokinase inhibitory activity tested as follows. Equal volumes of urokinase (u-PA) (2.5 CTA units/ml) and HUVEC conditioned medium or Con A eluates of the culture fluid were incubated for $30 \mathrm{~min}$ at $37^{\circ}$. Residual enzyme activity was measured by incubating $12.5 \mu \mathrm{l}$ of these mixtures containing $0.015 \mathrm{U}$ urokinase for $2 \mathrm{~h}$ at $37^{\circ} \mathrm{C}$, with $1 \mu \mathrm{g}$ glu-plasminogen, in a total volume of $0.2 \mathrm{ml}$ in $0.01 \mathrm{M} \mathrm{Na}_{2} \mathrm{HPO}_{4}, \mathrm{pH} \mathrm{7.4}$, containing $0.14 \mathrm{M} \mathrm{NaCl}, 0.01 \mathrm{M} \mathrm{EACA}, 0.25 \%$ gelatin, $0.006 \%$ Tween $20,0.1 \% \mathrm{NaN}_{3} .50 \mu \mathrm{l}$ of substrate solution containing a mixture of thiobenzylbenzyloxycarbonyl-L-lysinate $\left(0.68 \mathrm{mg} / \mathrm{ml} \mathrm{H}_{2} \mathrm{O}\right)$ and $5,5^{\prime}-$ dithiobis (2-nitrobenzoic acid) $(10 \mathrm{mg} / \mathrm{ml}$ dimethylformamide) in the ratio of $1: 11$ (vol:vol) was added and incubated at $37^{\circ} \mathrm{C}(31)$. Color development was followed at $405 \mathrm{~nm}$ in a Multitek ELISA plate reader. The concentration of plasminogen activator inhibitor per milliliter of HUVEC culture fluid or of chromatographic fraction was determined using a linear urokinase standard curve produced with enzyme concentrations of 0.002 to $0.015 \mathrm{U}$ per incubation mixture.

\section{Results}

Characteristics of HUVEC binding of $t-P A$. Upon exposure of HUVEC to t-PA, binding took place in a concentration-de- 
pendent and saturable manner (Fig. 1). At a t-PA level of 100 $\mathrm{IU} / \mathrm{ml}$ (14.6 $\mathrm{nM})$, binding approached saturation. This binding isotherm displayed an apparent $K_{\mathrm{d}}$ of $5.4 \pm 1.1 \mathrm{nM}$ (SE, $n$ $=5$ ). The binding isotherm for t-PA suggested the possibility of a two-component system with a rapid increase in binding at low $t-P A$ concentrations and a slower accumulation of binding at higher concentrations. HUVEC also bound u-PA, with saturation being approached at a u-PA concentration of $\sim 4 \mathrm{nM}$. Half-maximal u-PA binding was observed at a level of $\sim 1 \mathrm{nM}$ u-PA. Prothrombin, a protein that physically resembles t-PA and $\mathrm{u}-\mathrm{PA}$ in that it possesses a double "kringle" structure, served as control. Prothrombin was not bound by HUVEC under identical incubation conditions and concentration ranges. Binding of DFP-t-PA to HUVEC was essentially indistinguishable from that of untreated t-PA.

All antigen-antibody systems employed in the experiments were evaluated in serial plate dilutions and found to be sensitive at coating concentrations of $<1.0 \mathrm{ng} /$ well and antibody dilutions of up to 1:50,000. Furthermore, t-PA and plasminogen binding to HUVEC were mutually independent, since prior addition of either protein had no effect on binding of the other (data not shown).

As demonstrated in Fig. 2, HUVEC bound t-PA rapidly, reaching a steady state at $\sim 10 \mathrm{~min}$. Reversibility of binding was shown by "infinite dilution" of unbound ligand at $10 \mathrm{~min}$. At this time point, the t-PA dissociation curve was biphasic with a rapid initial dissociation phase during the first $2.5 \mathrm{~min}$ $\left(\mathrm{T}_{1 / 2}, 9 \mathrm{~min}\right)$ followed by a slower second phase over the next $24 \mathrm{~min}\left(\mathrm{~T}_{1 / 2}, 54 \mathrm{~min}\right)$. Under conditions utilized, $77 \%$ of total binding was dissociable.

Binding of t-PA by HUVEC was relatively specific for this cell type (Fig. 3). Control cells such as those from bovine endo-

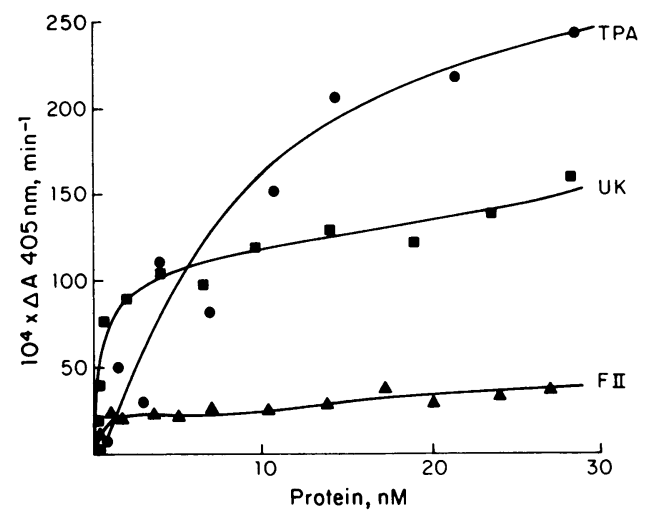

Figure 1. Interaction of t-PA, u-PA, and prothrombin with HUVEC. HUVEC were grown to confluency in plasminogen-depleted medium, equilibrated to $4^{\circ} \mathrm{C}$, and washed in IB and IB/EACA as described in Methods. HUVEC were then incubated for $30 \mathrm{~min}$ with various concentrations (0.4-28.4 $\mathrm{nM}$ ) of recombinant t-PA (๑), u-PA

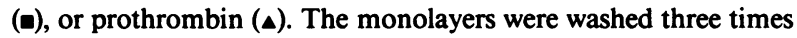
and lightly fixed with $0.02 \%$ glutaraldehyde. After three additional washes with PBS/Tween/BSA, rabbit anti-human t-PA, u-PA, or prothrombin at dilutions of $1: 1,000$ in PBS/Tween were added and incubated at $37^{\circ} \mathrm{C}$ for $3 \mathrm{~h}$. The monolayers were then washed again and exposed for $18 \mathrm{~h}$ at $4^{\circ} \mathrm{C}$ to alkaline phosphatase-conjugated goat anti-rabbit IgG diluted to 1:1,000 in PBS/Tween. After three additional washes, protein binding was measured as a reflection of change in absorbance over time. Each point represents the average of duplicate samples.

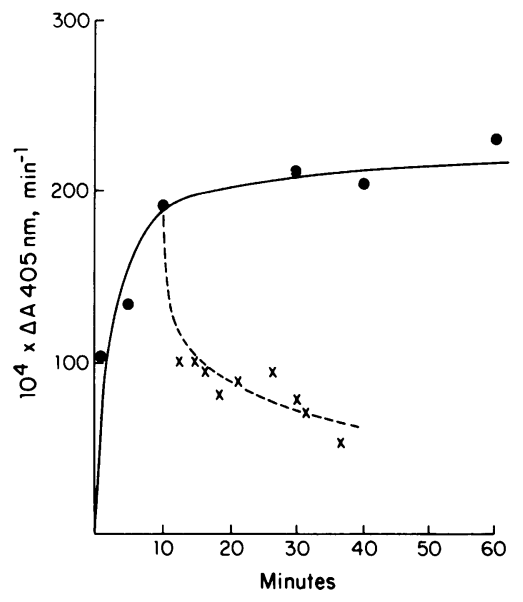

Figure 2. Time course and reversibility of t-PA binding to HUVEC. HUVEC, prepared as described in Fig. 1, were incubated with 100 $\mathrm{U} / \mathrm{ml}(14 \mathrm{nM}) \mathrm{t}-\mathrm{PA}$ $(100 \mu \mathrm{l} /$ well $)$ at $4^{\circ} \mathrm{C}$. At various time points (1-60 min), wells were emptied, washed five times rapidly (total wash time, $50 \mathrm{~s}$ ), and fixed with dilute glutaraldehyde (๑). Parallel wells $(x)$ were washed five times and filled

with $300 \mu \mathrm{l}$ IB starting at $10 \mathrm{~min}$ to effect 'infinite dilution' as previously described (24). These wells were subsequently washed three times and fixed at the indicated time points. Bound t-PA was assayed in each well as described in Fig. 1. The average of duplicate samples is shown.

thelium or smooth muscle failed to bind significant amounts of t-PA ( $1-5 \%$ of binding to HUVEC). Human foreskin fibroblasts and smooth muscle cells from internal mammary artery, cultured under equivalent conditions, demonstrated t-PA binding that was intermediate as compared with HUVEC. The apparent $K_{\mathrm{d}}$ for these cell types resembled that of HUVEC $(9.5$ and 12.6 vs. $9.0 \mathrm{nM}$ ). In contrast to HUVEC, however, the number of available binding sites was $\sim 50 \%$ less. These differences persisted when expressed on a "per cell" basis except for the binding of t-PA to human smooth muscle cells, which did approach that observed with HUVEC. In addition, passage number did not significantly affect binding of t-PA to HUVEC. The results indicated that species of origin and specific cell type, but not passage number, were important determinants of the interaction between t-PA and the cell surface.

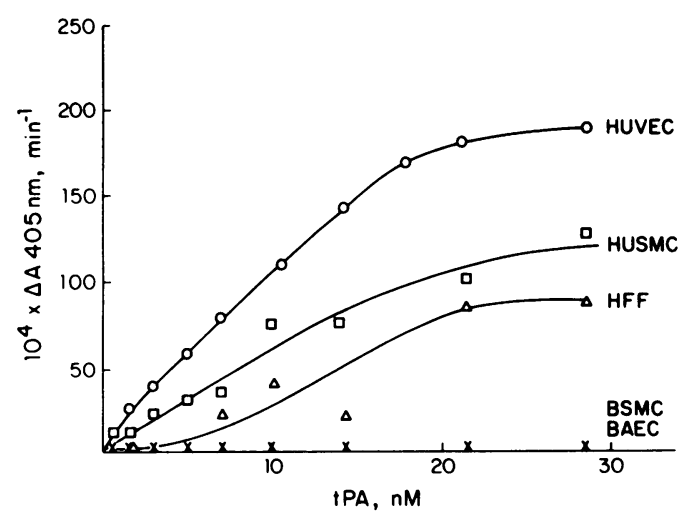

Figure 3. Binding of t-PA to various cell types. Human foreskin fibroblasts (passage 18; 79,000 cells/well), human internal mammary artery smooth muscle cells (passage 6;17,000 cells/well), and HUVEC (passage 3; 22,000 cells/well) were grown to confluency in M199 containing 20\% plasminogen-depleted human serum. Bovine smooth muscle cells (passage $5 ; 16,400$ cells/well) and bovine aortic endothelial cells (passage 14;35,000 cells/well) were grown in RPMI containing $20 \%$ plasminogen-depleted newborn calf serum. In all cases, cells were prepared and assayed as described in Fig. 1. Shown are the average of duplicate values. 
Inhibition of binding of ${ }^{125} \mathrm{I}$-t-PA by increasing molar excesses of unlabeled t-PA was quantified in a "cold competition assay" (Fig. 4). A fivefold molar excess of unlabeled t-PA induced $50 \%$ inhibition of ${ }^{125} \mathrm{I}-\mathrm{t}-\mathrm{PA}$ binding which indicated that the two ligands were nearly equal in competition for binding sites on HUVEC. A 100-125-fold molar excess of unlabeled t-PA-induced $85 \%$ inhibition of ${ }^{125} \mathrm{I}$-t-PA binding. In two experiments where it was tested, a 1,000-fold excess of cold t-PA blocked $95 \%$ of ${ }^{125}$ I-t-PA binding to HUVEC. Based on these results, we conclude that nonspecific binding represents $<15 \%$ of total binding.

Lysine binding sites are important functional determinants in the t-PA molecule and are implicated in the binding of t-PA to fibrinogen. Therefore, binding of t-PA by HUVEC was evaluated in the presence of lysine analogs (Table I). Omegaaminocarboxylic acids did inhibit binding of t-PA by HUVEC by $70-80 \%$, but relatively high concentrations of these acids were required to achieve such inhibition $\left(I_{50}, 38-54 \mathrm{mM}\right.$; $10^{5}-10^{6}$ fold molar excess). Binding could also be inhibited by $70-80 \%$ with the use of a chaotropic agent $\left(\mathrm{NH}_{4} \mathrm{SCN}, \mathrm{I}_{50}=65\right.$ $\mathrm{mM})$ or by increasing the ionic strength of the medium $(\mathrm{NaCl}$, $I_{50}=135 \mathrm{mM}$ ). In addition, binding of t-PA by HUVEC could not be inhibited by a 100 -fold molar excess of fluid phase fibrinogen (Fig. 5). It was therefore concluded that lysine binding sites of t-PA per se did not play a major role in the binding interaction between HUVEC and t-PA.

Inhibition of $t-P A$ binding by $u$ - $P A$. The ability of HUVEC to bind t-PA in the presence of excess quantities of several control proteins including u-PA was studied (Fig. 5). Murine epidermal growth factor, human fibrinogen, prothrombin, plasminogen, plasminogen "kringle" $1,2,3$, and fibronectin did not induce significant inhibition of t-PA binding. However, HUVEC binding of t-PA was blocked by urokinase in a concentration-dependent manner. At a 14.5 4 4.0 (SE, $n=6$ )fold molar excess of $\mathrm{u}-\mathrm{PA}, 50 \%$ inhibition of binding was observed. A 50-100-fold excess of u-PA blocked binding by $\sim 70 \%$. As demonstrated by SDS-PAGE autoradiography, inhibition of binding by u-PA was not due to proteolytic cleavage of t-PA (data not shown). These results indicate that t-PA and u-PA probably share a common binding site on the HUVEC surface.

Binding interaction between HUVEC and ${ }^{125}$ I-t-PA. To precisely quantify the binding affinity and capacity of HUVEC

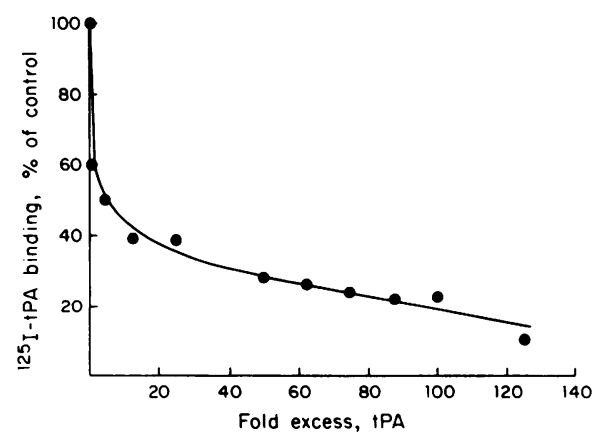

Figure 4. Inhibition of ${ }^{125} \mathrm{I}-\mathrm{t}-\mathrm{PA}$ binding with excess unlabeled t-PA. HUVEC in 24-well tissue culture dishes were prepared as described in Fig. 1. The cells were incubated at $4^{\circ} \mathrm{C}$ with ${ }^{125} \mathrm{I}$-t-PA $(147,000$ $\mathrm{cpm} / \mathrm{pmol} ; 2.7 \mathrm{nM})$ containing increasing molar excesses $(0-125)$ of unlabeled t-PA. Bound ${ }^{125} \mathrm{I}-\mathrm{t}-\mathrm{PA}$ was measured as in Fig. 6. Average values for duplicate samples are shown.
Table I. Effect of Various Agents on t-PA Binding to HUVEC

\begin{tabular}{ll}
\hline Inhibitor & $I_{\mathbf{s 0}}$ \\
\hline & $m M$ \\
t-AMCHA & $45 \pm 18$ \\
EACA & $44 \pm 13$ \\
l-Lysine & $38 \pm 5$ \\
l-Arginine & $54 \pm 7$ \\
$\mathrm{NH}_{4} \mathrm{SCN}$ & $65 \pm 10$ \\
\hline
\end{tabular}

t-PA (14.6 nM) was mixed with varying concentrations of inhibitors, and binding to HUVEC assayed as described in the legend to Fig. 1. Each $I_{50}$ was determined as that inhibitor concentration which blocked t-PA binding by $50 \%$. Values shown are means $\pm \mathrm{SE}, n=3$.

for t-PA, we carried out radioligand binding experiments to confirm and extend results obtained with unlabeled ligand. In a manner similar to unlabeled t-PA, ${ }^{125} \mathrm{I}-\mathrm{t}-\mathrm{PA}$ was bound by HUVEC in a concentration-dependent reaction (Fig. 6). At a t-PA concentration of 28-40 nM, binding approached saturation levels at which point each $1.7-\mathrm{cm}$ monolayer bound $\sim 9.1 \mathrm{ng}$ of t-PA at the highest quantities tested. As depicted in Fig. 6, Scatchard plot analysis of the data suggested that the binding system had two components $(P<0.0001)$ with high $\left(K_{\mathrm{d}}, 28.7 \pm 10.8 \mathrm{pM} ; \mathrm{B}_{\max }, 3,700 \pm 300\right.$ binding sites per cell; $\mathrm{SE}$, $n=3)$ and low $\left(K_{\mathrm{d}}, 18.1 \pm 3.8 \mathrm{nM} ; \mathrm{B}_{\max }, 815,000 \pm 146,000\right.$ binding sites per cell; SE, $n=3$ ) affinity binding sites. Given the expected error for this type of measurement, the $K_{d}$ established for the low affinity site was in reasonable agreement with that obtained in the ELISA studies reported above.

Functional properties of bound $t-P A$. Experiments were carried out to determine whether the t-PA bound by HUVEC still retained its capacity for plasminogen activation. We found that fluid phase activation of plasminogen by t-PA followed Michaelis-Menten kinetics, as reported by other investigators $(8,32)$. When t-PA was bound to HUVEC, plasminogen activation by the bound material also conformed to MichaelisMenten kinetics as demonstrated by linear Lineweaver-Burk plots. The catalytic efficiency of bound t-PA was compared with that of an equivalent quantity of fluid phase t-PA with the use of a fluorometric assay for t-PA activity. In three separate experiments it could be demonstrated that binding of $t-P A$ to HUVEC resulted in an average 2.6 -fold decrease in the cata-

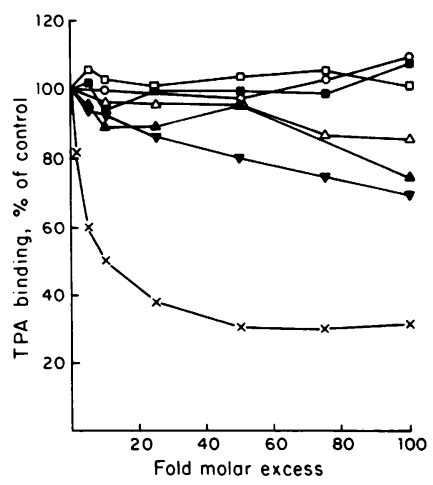

Figure 5. Effect of structurally related proteins on binding of t-PA to HUVEC. HUVEC, prepared as described in Fig. 1, were incubated for $30 \mathrm{~min}$ at $4^{\circ} \mathrm{C}$ with t-PA $(10 \mathrm{U} / \mathrm{ml} ; 100$ $\mu \mathrm{l} /$ well) and various-fold molar excesses $(0-100)$ of the following proteins: urokinase $(x)$, murine epidermal growth factor $(\boldsymbol{\square})$, plasminogen $(\boldsymbol{\triangle})$, elastase-derived plasminogen kringle $1,2,3(\Delta)$, fibronectin $(\nabla)$, fibrinogen ( $\square$ ), and prothrombin (O). After three washes with IB, HUVEC were assayed as described (Fig. 1) for t-PA binding. The average of duplicate samples is shown for each protein. 


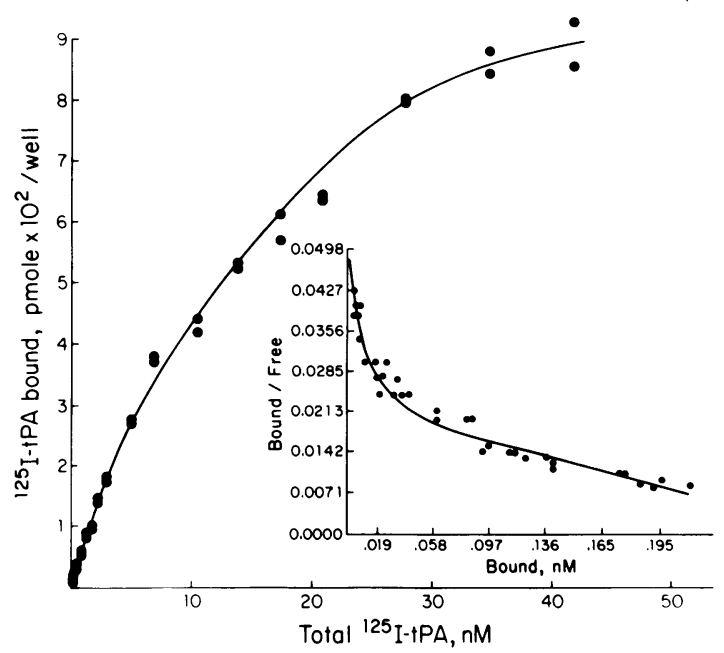

Figure 6. Binding of ${ }^{125}$ I-t-PA to HUVEC. HUVEC grown to confluency in 24-well plates in plasminogen-depleted medium were washed once in IB(5), once in IB(5)/EACA, and three times in IB(5). ${ }^{125}$ I-t-PA (sp act, $149,000 \mathrm{cpm} / \mathrm{pmol}$ ), diluted in various ratios with unlabeled t-PA, was added to duplicate wells $(450 \mu \mathrm{l} /$ well) and incubated at $4^{\circ} \mathrm{C}, 30 \mathrm{~min}$. Unbound radioactivity from a $100-\mu \mathrm{l}$ aliquot was sampled before emptying and washing each well rapidly five times (total wash time, $45 \mathrm{~s}$ ). Bound radioactivity was recovered in the washed cell fraction solubilized in $1 \%$ SDS/0.5 M NaOH/0.01 M EDTA, and counted as a 100- $\mu$ l aliquot. (Inset) Scatchard plot. Data were analyzed according to the Ligand program of Munson and Rodbard (28).

lytic rate constant $\left(k_{\text {cat }}\right)$, accompanied by an eightfold decrease in apparent $K_{\mathrm{m}}$ (Table II). This was reflected by a significant (average 3.2-fold) increase in catalytic efficiency $\left(k_{\text {cat }} / K_{\mathrm{m}}\right)$. Direct linear plot was used to verify calculated values for $V_{\max }$ and $K_{\mathrm{m}}$ (Enzpack program, Elsevier-Biosoft; Cambridge, UK). HUVEC alone produced negligible amounts of fluid phase plasminogen activation over a period of several hours. Therefore, the effect observed was not due to elaboration of plasminogen activators in the fluid phase. It was concluded that cell-bound t-PA retained full functional capacity and was at least as strong a catalytic agent as t-PA in the fluid phase.

$\mathrm{t}-\mathrm{PA}$ in the fluid phase is known to be susceptible to rapid inhibition by plasminogen activator inhibitor (PAI). We tested the inhibitory effect of PAI-enriched postculture medium on t-PA which was bound to HUVEC (Table III). At molar ratios of up to 20:1 (PAI:t-PA), bound t-PA was insensitive to this

Table II. Kinetic Parameters of Plasminogen Activation by $t-P A$

\begin{tabular}{lrll}
\hline State of t-PA & \multicolumn{1}{l}{$K_{\mathrm{m}}$} & \multicolumn{1}{l}{$k_{\text {cat }}$} & $k_{\text {cat }} / K_{\mathrm{m}}$ \\
\hline & $n M$ & $\mathrm{~min}^{-1}$ & $\mu M^{-1}, \mathrm{~min}^{-1}$ \\
HUVEC & $241 \pm 23$ & $0.00717 \pm 0.00261$ & $0.0324 \pm 0.0126$ \\
Fluid phase & $1,863 \pm 64$ & $0.0187 \pm 0.0040$ & $0.0102 \pm 0.0023$
\end{tabular}

Kinetic parameters were derived from activation data from three separate experiments. $K_{\mathrm{m}}$ and $V_{\max }$ were calculated from the Lineweaver-Burk plot $x$ - and $y$-intercepts, respectively, utilizing least squares linear regression analysis. The catalytic rate constant $\left(k_{\text {cat }}\right)$ was derived from the expression $V_{\max } /\left[\mathrm{E}_{\mathrm{o}}\right]$, where $\left[\mathrm{E}_{\mathrm{o}}\right]=214 \mathrm{pM}$ t-PA. Catalytic efficiency is represented as $k_{\text {cat }} / K_{\mathrm{m}}$. Shown are mean values $\pm \mathrm{SE}, n=3$.
Table III. Inhibition of t-PA by PAI: $I_{50}$ (Molar Ratio)

$$
\begin{aligned}
& \text { Fluid phase } \\
& \text { HUVEC-bound }
\end{aligned}
$$

$0.493 \pm 0.026$

No inhibition
t-PA inhibitory activity was measured in a fluorogenic assay system consisting of plasminogen ( $154 \mathrm{nM}$ ), AFC plasmin substrate (167 $\mu \mathrm{M})$, fluid phase $(0.214 \mathrm{nM})$ or cell surface-bound t-PA, and various molar ratios of PAI. t-PA activity was measured in relative fluorescence units as previously described (24) for wells containing or lacking HUVEC, and the molar ratio (PAI:t-PA) that produced $50 \%$ inhibition of substrate hydrolysis was calculated. Values shown are mean $\pm \operatorname{SE}(n=4)$.

inhibitor, whereas fluid phase t-PA was inhibited by $50 \%$ at an estimated molar ratio of $0.5: 1$. This inhibitory factor in postculture medium was $85-90 \%$ adsorbed by antibody to human PAI-1 at a dilution of 1:50, but not by similar concentrations of a control antibody (mouse anti-human $F_{c}$ receptor), in the presence of protein A-Sepharose. In addition, preincubation of PAI-enriched post-culture medium with confluent monolayers of HUVEC $\left(22^{\circ} \mathrm{C}, 150 \mathrm{~min}\right)$ did not significantly reduce its t-PA-inhibitory activity, suggesting that PAI was not adsorbed by the cells and also that the cells did not produce a product that competes with or inactivates PAI. Thus, the data indicate that following binding of t-PA by HUVEC, the active site of the enzyme becomes relatively inaccessible to this physiologic inhibitor, suggesting that its fibrinolytic potential would be enhanced.

\section{Discussion}

Results of the present study constitute the first demonstration of specific tissue plasminogen activator binding to monolayers of human umbilical vein endothelial cells. The interaction of t-PA with HUVEC was protein-specific, although other "kringle"-containing proteins such as plasminogen and plasmin also bound to the HUVEC surface (24). However, a nonfibrinolytic "kringle"-containing protein, prothrombin (33), was not bound at all by HUVEC. The binding reaction was species-specific, because t-PA bound with varying affinity to three human cell types (endothelial cells, fibroblasts, and smooth muscle cells), but not to two bovine cell lines (endothelium and smooth muscle) (Fig. 3). Among the human cells tested, binding was relatively cell surface-specific; human fibroblasts and smooth muscle cells bound t-PA in an intermediate manner compared with endothelial cells grown under the same conditions. Two different binding assay systems (ELISA and ${ }^{125}$ I-ligand) indicated that binding was saturable. With regard to the major binding site, both methods yielded similar isotherms with $K_{\mathrm{d}} \mathrm{s}$ of $\sim 5.4$ and $18.1 \mathrm{nM}$, respectively. Binding of t-PA and plasminogen were mutually independent phenomena, because pretreatment of cells with either protein did not enhance binding of the other, and neither plasminogen nor K123 competed with t-PA for binding to the cell surface (Fig. 5).

The interaction of t-PA with cultured HUVEC is a two-site binding system. This was evidenced by the radioligand binding data which clearly indicated two discrete saturable binding sites $(P<0.0001)$. The shape of the binding isotherms also suggested a two-site system, wherein a rapid increase in binding at low t-PA input concentrations was followed by a more 
gradual increase in binding as higher concentrations were approached (Fig. 1, 3, and 6). Furthermore, the shape of the binding dissociation curve also suggested a two-phase process with different rates of dissociation (Fig. 2). Even though the radioligand binding studies were not carried out under strict equilibrium conditions, reasonable estimates of binding affinity and capacity were provided via excellent agreement with those obtained by ELISA. Finally, the cold competition assay system validated the ${ }^{125} \mathrm{I}-\mathrm{t}-\mathrm{PA}$ data by providing verification that labeled and unlabeled ligand competed for the cell surface with approximately equal affinity (Fig. 4).

Under baseline conditions, the level of t-PA in human plasma is $50-100 \mathrm{pM}(14,34,35)$; following physical exercise, vaso-occlusion, or infusion of 1-deamino-8-D-arginine vasopressin (DDAVP), plasma levels of t-PA increase threefold (34, $35)$. Because our binding studies have demonstrated a high affinity $K_{\mathrm{d}}$ for the t-PA-HUVEC interaction $(\sim 29 \mathrm{pM})$, circumstances in which t-PA is released from the vascular wall would result in plasma t-PA levels which would equal or exceed this value. In addition, levels of t-PA in the endothelial cell microenvironment might transiently reach even higher levels and therefore exert a favorable influence upon binding of t-PA to the endothelial cell surface. Thus the interactions observed in our experiments are of possible physiological relevance especially under conditions promoting t-PA release, such as venous occlusion or physical stress.

The precise mechanism whereby HUVEC bound t-PA to their surface remains to be elucidated. Although the fibrinbinding domain of t-PA involves the "kringle"- 2 segment (and to a lesser extent the fibronectin "finger" and epidermal growth factor regions $[36,37])$, it is unlikely that the fibrin binding domain of t-PA is germane to the interactions we studied. This is evidenced by our demonstration that the HUVEC employed in these experiments contained insufficient surface fibrinogen to account for the degree of binding attained. Furthermore, binding of t-PA to the HUVEC surface was not blocked by fluid phase fibrinogen (Fig. 5). In addition, relatively high $(\mathrm{mM})$ concentrations of lysine analogs are required to induce significant inhibition of t-PA binding, and the inhibition that did occur may have been a reflection of an increase in ionic strength of the medium (Table I). Whereas plasminogen does exhibit a lysine binding site-dependent interaction with the HUVEC surface (24), neither plasminogen nor its elastase-derived fragment, "kringle 1,2,3", blocked binding of t-PA by HUVEC, even when present in 100-fold molar excess (Fig. 5).

Although urokinase strongly inhibits t-PA binding to HUVEC, other proteins which are structurally homologous (epidermal growth factor, plasminogen, plasminogen-derived "kringle" 1,2,3, fibronectin, fibrinogen, and prothrombin) did not do so (Fig. 5). Both urokinase and t-PA both possess growth factor, "kringle," and catalytic domains which demonstrate varying degrees of homology $(6,7)$. The amino terminal fragment of u-PA which contains the growth factor and "kringle" domains appears to mediate u-PA binding to human monocytic and epidermoid carcinoma cell lines (38). As depicted in Fig. 5, one of these two or possibly an as yet undefined domain may be responsible for the binding function of t-PA by HUVEC.

It is important to note that t-PA retains its activity as a catalytic agent after it has been bound by HUVEC (Table II).
This did not represent release of a soluble endothelial cell component(s) because endothelial cell postculture medium was incapable of activating plasminogen in the time frame of this assay. Upon binding of t-PA by HUVEC, we measured a 3.2fold increase in its catalytic efficiency (Table II). Upon binding of t-PA to fibrin, the same reaction proceeds $\sim 500$ times more efficiently (8), suggesting that the endothelial cell may have a fibrinlike effect, albeit of much lower magnitude. The basis of the HUVEC-induced increase in catalytic efficiency, like that conferred by fibrin, was a decrease (eightfold) in the apparent $K_{\mathrm{m}}$. We have previously demonstrated (24) that plasminogen also binds to HUVEC, and that binding augments its activatability by 12 -fold, based on a proportionate decrease in apparent $K_{\mathrm{m}}$. The concentrations of plasminogen used in the t-PA activation experiments were at or below the $K_{\mathrm{d}}$ for the interaction of plasminogen with HUVEC. Thus, under these assay conditions, plasminogen binding sites could be partially occupied, and the eightfold decrease in $K_{\mathrm{m}}$ observed for plasminogen activation by cell surface t-PA may reflect, at least in part, a contribution from plasminogen bound to the cell surface.

The endothelial cell surface appears to confer protection of t-PA with respect to its physiologic inhibitor, PAI. Although the mechanism for this protection is unclear, this phenomenon has been reported in other enzyme systems. Thus, plasmin bound to a fibrin surface is sequestered from the action of circulating antiplasmin (39), and acrosin from ram seminal vesicle is protected from its inhibitor in seminal plasma (40). In cellular systems, urokinase which becomes macrophage-associated is not susceptible to the action of PAI, whereas plasminogen activator in the fluid phase is exquisitely sensitive to PAI $(41,42)$. Therefore, active site protection, whereby proteases acquire increased catalytic activity upon association with physiologically relevant surfaces, may represent a broad physiologic mechanism. This protection is of pertinence in our system, because the phenomenon augments fibrinolytic potential in a plasma milieu where a thrombus might be located in the in vivo situation.

In previous studies (24), we demonstrated that plasminogen, the major substrate for t-PA, bound in a specific manner and with high affinity to cultured HUVEC in physiologic concentrations. Data presented in the experiments described have indicated that t-PA was also bound in vitro under comparable circumstances. Similar data concerning binding of plasminogen and urokinase to the promyeloid leukemic cell line (U937) and a fetal lung fibroblast cell line (GM1380) have been recently reported by Plow et al. (43). The binding described in the present study may be physiologically relevant in the course of events such as venous occlusion or physical stress. Although the t-PA binding site was not identical to the plasminogen binding site or plasminogen itself, the reaction allowed t-PA to retain its ability to activate plasminogen and the bound t-PA was inaccessible to its rapidly-acting inhibitor, PAI. Therefore, the endothelial cell, by virtue of its ability to provide specific binding sites for the assembly of proteins of the fibrinolytic system, may serve as a focal point for plasmin generation in the blood vessel microenvironment.

\section{Acknowledgments}

Dr. Hajjar is the recipient of Clinical Investigator Award KO8 HL-01352 from the National Institutes of Health, and an Andrew W. 
Mellon Foundation Teacher-Scientist Award. This work was also supported by grant HL-18828 (Specialized Center of Research in Thrombosis) from the National Institutes of Health.

\section{References}

1. Bachmann, F., and E. K. O. Kruithof. 1984. Tissue plasminogen activator: chemical and physiological aspects. Semin. Thromb. Hemostasis. 10:6-17.

2. Wallen, P., M. Ranby, N. Bergsdorf, and P. Kok. 1981. Purification and characterization of tissue plasminogen activator: on the occurrence of two different forms and their enzymatic properties. In Progress in Fibrinolysis. J. F. Davidson, I. M. Nilsson, and B. Astedt, editors. Churchill/Livingstone, Edinburgh. 16-23.

3. Rijken, D. C., and E. Groeneveld. 1986. Isolation and functional characterization of the heavy and light chains of human tissue-type plasminogen activator. J. Biol. Chem. 261:3098-3102.

4. Banyai, L., A. Varadi, and L. Patthy. 1983. Common evolutionary origin of the fibrin-binding structures of fibronectin and tissue-type plasminogen activator. FEBS (Fed. Eur. Biochem. Soc.) Lett. 163:3741.

5. Pennica, D., W. E. Holmes, W. J. Kohr, R. N. Harkins, G. A. Vehar, C. A. Ward, W. E. Bennett, E. Yelverton, P. H. Seeburg, H. L. Heyneker, D. V. Goeddel, and D. Collen. 1983. Cloning and expression of human tissue-type plasminogen activator cDNA in $E$. Coli. Nature (Lond.). 301:214-221.

6. Strassburger, W.; A. Wollmer, J. E. Pitts, I. D. Glover, I. J. Tickle, T. L. Blundell, G. J. Steffens, W. A. Gunzler, F. Otting, and L. Flohe. 1983. Adaptation of plasminogen activator sequences to known protease structures. FEBS (Fed. Eur. Biochem. Soc.) Lett. 157:219223.

7. Ny, T., F. Elgh, and B. Lund. 1984. The structure of the human tissue-type plasminogen activator gene: correlation of intron and exon structures to functional and structural domains. Proc. Natl. Acad. Sci. USA. 81:5355-5359.

8. Hoylaerts, M., D. C. Rijken, H. R. Lijnen, and D. Collen. 1982. Kinetics of the activation of plasminogen by human tissue plasminogen activator. J. Biol. Chem. 257:2912-2919.

9. Silverstein, R. L., R. L. Nachman, L. L. K. Leung, and P. C. Harpel, 1985. Activation of immobilized plasminogen by tissue activator: multimolecular complex formation. J. Biol. Chem. 260:1034610352.

10. Loskutoff, D. J., and T. S. Edgington. 1977. Synthesis of a fibrinolytic activator and inhibitor by endothelial cells. Proc. Natl. Acad. Sci. USA. 74:3903-3907.

11. Levin, E. G., and D. J. Loskutoff. 1982. Cultured bovine endothelial cells produce both urokinase and tissue-type plasminogen activators. J. Cell Biol. 94:631-636.

12. Booyse, F. M., G. Osikowicz, S. Feder, and J. Scheinbuks. 1984. Isolation and characterization of a urokinase-type plasminogen activator $\left(M_{r}=54,000\right)$ from cultured human endothelial cells indistinguishable from urinary urokinase. J. Biol. Chem. 259:7198-7205.

13. Van Mourik, J. A., D. A. Lawrence, and D. J. Loskutoff. 1984. Purification of an inhibitor of plasminogen activator (antiactivator) synthesized by endothelial cells. J. Biol. Chem. 259:14914-14921.

14. Erickson, L. A., R. R. Schleef, T. Ny, and D. J. Loskutoff. 1985. The fibrinolytic system of the vascular wall. Clin. Haematol. 14:513530 .

15. Moscatelli, D. 1986. Urokinase-type and tissue-type plasminogen activators have different distributions in cultured bovine capillary endothelial cells. J. Cell. Biochem. 30:19-29.

16. Vassalli, J.-D., D. Baccino, and D. Belin. 1985. A cellular binding site for the $M_{r} 55,000$ form of the human plasminogen activator, urokinase. J. Cell Biol. 100:86-92.

17. Stoppelli, M. P., A. Corti, A. Soffienrini, G. Cassani, F. Blasi, and R. K. Assoian. 1985. Differentiation-enhanced binding of the amino-terminal fragment of human urokinase plasminogen activator to a specific receptor on U937 monocytes. Proc. Natl. Acad. Sci. USA. 82:4939-4943.

18. Del Rosso, M., G. Dini, and G. Fibbi. 1985. Receptors for plasminogen activator, urokinase, in normal and Rous sarcoma virustransformed mouse fibroblasts. Cancer Res. 45:630-636.

19. Keski-Oja, J., and A. Veheri. 1982. The cellular target for the plasminogen activator, urokinase, in human fibroblasts $-66,000$-dalton protein. Biochim. Biophys. Acta. 720:141-146.

20. Fibbi, G., G. Dini, F. Pasquali, M. Pucci, and M. Del Rosso. 1986. The $M_{r} 17,500$ region of the $A$ chain of urokinase is required for interaction with a specific receptor in A431 cells. Biochim. Biophys. Acta. 885:301-308.

21. Stoppelli, M., C. Tacchetti, M. V. Cubellis, A. Corti, V. J. Hearing, G. Cassani, E. Appella, and F. Blasi. 1986. Autocrine saturation of pro-urokinase receptors on human A431 cells. Cell. 45:675684.

22. Gross, J. L., M. N. Krupp, D. B. Rifkin, and M. D. Lane. 1983. Down-regulation of epidermal growth factor receptor correlates with plasminogen activator activity in human A431 epidermoid carcinoma cells. Proc. Natl. Acad. Sci. USA. 80:2276-2280.

23. Shuman, M. A., and C. H. Merkel. 1985. Urokinase binding to bovine corneal endothelial cells. Exp. Eye Res. 41:371-382.

24. Hajjar, K. A., P. C. Harpel, E. A. Jaffe, and R. L. Nachman. 1986. Binding of plasminogen to cultured human endothelial cells. $J$. Biol. Chem. 261:11656-11662.

25. Sottrup-Jensen, L., H. Claeys, M. Zajdel, T. E. Petersen, and S. Magnusson. 1978. The primary structure of human plasminogen: isolation of two lysine-binding fragments and one "mini-" plasminogen (MW, 38,000) by elastase-catalyzed-specific limited proteolysis. In Progress in Chemical Fibrinolysis and Thrombolysis. Vol. 3. J. F. Davidson, R. M. Rowan, M. M. Samama, and P. C. Edsnoyers, editors. Raven Press, New York. 191-209.

26. Martin, B. M., W. W. Wasiewski, J. W. Fenton, and T. C. Detwiler. 1976. Equilibrium binding of thrombin to platelets. Biochemistry. 15:4886-4893.

27. Laemmli, U. K. 1970. Cleavage of structural proteins during the assembly of the head of bacteriophage $\mathrm{T}_{4}$. Nature (Lond.). 227:680-684.

28. Munson, P. J., and D. Rodbard. 1980. Ligand: a versatile computerized approach for characterization of ligand-binding systems. Anal. Biochem. 107:220-239.

29. Nachman, R. L., K. A. Hajjar, R. L. Silverstein, and C. A. Dinarello. 1986. Interleukin 1 induces endothelial cell synthesis of plasminogen activator inhibitor. J. Exp. Med. 163:1595-1600.

30. Andreasen, P. A., L. S. Nielsen, P. Kristensen, J. GrondahlHansen, L. Skriver, and K. Dano. 1986. Plasminogen activator inhibitor from human fibrosarcoma cells binds urokinase-type plasminogen activator, but not its proenzyme. J. Biol. Chem. 261:7644-7651.

31. Green, G. D. J., and E. Shaw. 1979. Thiobenzyl benzyloxycarbonyl-L-lysinate, substrate for a sensitive colorimetric assay for trypsin-like enzymes. Anal. Biochem. 93:223-226.

32. Ranby, M. 1982. Studies on the kinetics of plasminogen activation by tissue plasminogen activator. Biochim. Biophys. Acta. 704:461-469.

33. Magnusson, S., T. E. Petersen, L. Sottrup-Jensen, and H. Claeys. 1975. Complete primary structure of prothrombin. In Proteases and Biologic Control. E. Reich, D. B. Rifkin, and E. Shaw, editors. Cold Spring Harbor Laboratories, Cold Spring Harbor, NY. 123-149.

34. Bergsdorf, N., T. Nilsson, and P. Wallen. 1983. An enzyme linked immunosorbent assay for determination of tissue plasminogen activator applied to patients with thromboembolic diseases. Thromb. Haemostasis. 50:740-744.

35. Rijken, D. C., I. Juhan-Vague, F. DeCock, and D. Collen. 1983. 
Measurement of human tissue-type plasminogen activator by a twosite immunoradiometric assay. J. Lab. Clin. Med. 101:274-284.

36. Ichinose, A., K. Takio, and K. Fujikawa. 1986. Localization of the binding site of tissue-type plasminogen activator to fibrin. J. Clin. Invest. 78:163-169.

37. Van Zonneveld, A., H. Veerman, and H. Pannekoek. 1986. Autonomous function of structural domains on human tissue-type plasminogen activator. Proc. Natl. Acad. Sci. USA. 83:4670-4674.

38. Cubellis, M. V., M. L. Nolli, G. Cassani, and F. Blasi. 1986. Binding of single-chain prourokinase to the urokinase receptor of human U937 cells. J. Biol. Chem. 261:15819-15822.

39. Wiman, B., and D. Collen. 1978. Molecular mechanism of physiologic fibrinolysis. Nature (Lond.). 272:549-550.

40. Brown, C. R., and E. F. Hartree. 1976. Effects of acrosin inhibi- tors on the soluble and membrane-bound forms of ram acrosin, and a reappraisal of the role of the enzyme in fertilization. Hoppe-Seyler's $Z$. Physiol. Chem. 357:57-65.

41. Chapman, H. A., Z. Vavrin, and J. B. Hibbs. 1982. Macrophage fibrinolytic activity: identification of two pathways of plasmin formation by intact cells and of a plasminogen activator inhibitor. Cell. 28:653-662.

42. Chapman, H. A., O. L. Stone, and Z. Vavrin. 1984. Degradation of fibrin and elastin by intact human alveolar macrophages in vitro. J. Clin. Invest. 73:806-815.

43. Plow, E. F., D. E. Freaney, J. Plescia, and L. A. Miles. 1986. Evidence for plasminogen and urokinase receptors on the same cell type. J. Cell Biol. 103:2411-2420. 